The Review of Finance and Banking

print ISSN 2067-2713, online ISSN 2067-3825

Volume 11, Issue 1, Year 2019

http://dx.doi.org/10.24818/rfb.19.11.01.02, Pages 14-23

\title{
DO REAL EXCHANGE RATE CHANGES HAVE SYMMETRIC OR ASYMMETRIC EFFECTS ON TRADE BALANCE IN NIGERIA? EVIDENCE FROM NON-LINEAR ARDL MODEL
}

\author{
ONATUNJI OLUFEMI
}

\begin{abstract}
This paper investigates the asymmetric impact of real exchange changes on trade balance in Nigeria using quarterly data over the period 1999Q1-2017Q4. A non-linear Autoregressive Distributed Lag (NARDL) proposed by Shin et al (2014) is employed for this study. The findings show that real exchange change have asymmetric impact on Nigeria's trade balance in both time horizons. Specifically, the positive real exchange rate is highly sensitive to trade balance than the negative real exchange rate. These findings therefore suggest that using discretionary monetary policy to offset Nigeria's trade deficit due to large differential between import and export is not sufficient enough. Thus, policy makers should adopt policy-mix to manage the current economic climate of the country such as imposition of quotas on certain imported goods, high tariff rate on imported goods, provision of credit facilities and higher tax rate that reduce disposable income of consumer.
\end{abstract}

\section{INTRODUCTION}

Since the breakdown of Bretton Woods system in 1973, many countries have shifted from fixed exchange rate regime to variants of flexible exchange rate regime. This transition has degenerated into macroeconomic volatilities which have been the subject of considerable research and policy discussion among researchers and policy makers around the globe. Following these, the impact of exchange rates on other macroeconomic variables, particularly, trade balance has been a hotly debate discussion in the empirical literature with inconclusive findings. Several studies asserted that depreciation of a domestic currency will increase the international competitiveness of a country which ultimately corrects its trade deficit (see for recent studies, Kondongo and Ojah, 2012; Umoru and Oseme, 2013; Tunaer Vural, 2015; Demian and Mauro, 2017 among others). Similarly, International organizations such as the World Bank and the International Monetary Fund (IMF) have been proposing currency devaluation as a contrivance for alleviating balance of payments problems and promoting economic growth and stabilization in less developed countries (LDC) (Bhattarai and Armah, 2005; and Eke et al, 2015 ). However, depreciating of a country's domestic currency might not proffer resolutions to the trade deficit crunch of such small open economy like Nigeria.

Most policymakers and researchers have been at variance on the dynamic interaction between exchange rate changes and trade balance. several studies concluded that the exchange ratetrade nexus are symmetric; that is, if a depreciation of domestic currency improve trade balance, then a domestic currency appreciation should deteriorate trade balance in the same magnitude ( see, for instance, Bahmani-Oskoee and Fariditavana, 2015; Arize et al, 2017 and BahmaniOskoee and Karameliki, 2018) and these conflicting findings have resulted in wrong policy

Received by the editors February 6, 2019. Accepted by the editors June 27, 2019.

Keywords: Real exchange rate, Trade balance, Non-linear ARDL..

JEL Classification: F13, F39, F40.

Onatunji Olufemi, Department of Economics, Obafemi Awolowo University, Ile-Ife, Nigeria. E-mail: gphe$\max 12 @$ gmail.com.

This paper is in final form and no version of it will be submitted for publication elsewhere. 
suggestions for different countries due to dearth of cognizance of the asymmetric relationship between exchange rate and trade balance.

Following the aggregation bias of the previous empirical studies, a new line of studies ${ }^{1}$ have been evolving in investigating the asymmetric relationships between exchange rate changes and trade balance. This new strand of studies confirmed that, in the case of asymmetric exchange rate, risk- averse investors might respond strongly to depreciation of domestic currency and not react to appreciation of domestic currency due to the non-linear relationship between the variables. Thus, to address these dichotomy issues on the aggregation bias in the empirical literature. This study opens a new line of inquiry by exploring further on the exchange rate trade balance nexus in the case of Nigeria using the recently developed time series techniques, Non-linear ARDL developed by Shin et al (2014) to explore the asymmetric relationship between exchange rate changes and trade balance in the case of Nigeria. The novelty of this study is based on the following:

First, the exchange rate-trade nexus have been well documented in the advanced countries using aggregated-level data, disaggregated commodity or industry-level data. However, only a few studies have been investigated in the case of developing or emerging countries like Nigeria and most of their empirical findings are inconclusive which open a new line of investigation for this study. Second, with the exception of Aliyu and Tijjani $(2015)^{2}$, previous studies conducted in Nigeria have employed the linear econometric techniques such as Johansen Maximum Likelihood (JML), Vector Autoregressive (VAR), vector error-correction model (VECM), Autoregressive distributed lag (ARDL) among others (see, for recent studies, Afsegbua, 2012; Ogundipe et al, 2013; Umuru and Oseme, 2013; Igue and Ogunleye, 2014; Michael and Emeka, 2017; Eke et al, 2015 and Rasaq et al, 2017 among others). Thus, this study employs the Non-linear ARDL technique to examine the asymmetric effect of exchange rates changes on trade balance in the case of Nigeria. Third, this study also validates the existence of J-curve or Marshal-Lerner hypothesis for the case of Nigeria.

The remainder of the paper is organized as follows. Section 2 introduces the model specifications (linear and Non-linear ARDL approach) employed in this study. Section 3 presents the data and empirical results and section 4 provides the concluding remarks.

\section{Methodology}

To uncover the asymmetric effect of exchange rate changes on trade balance in Nigeria, this study adapts the model of Rose and Yellen (1989), Wang et al (2012) and Bahmani-Oskoee and Karamelikli (2018) which are formulated as follows:

$$
\ln T B_{t}=\alpha+\beta_{1} \ln Y_{t}^{D}+\beta_{2} \ln Y_{t}^{F}+\beta \ln R E X_{t}+\varepsilon_{t}
$$

Where $T B$ is the trade balance that measures the ratio of a Nigerian export to its trading partner countries over its import from them; $Y_{t}^{D}$ denotes as the real income of Nigeria; $Y_{t}^{F}$ is the real income of the trading partner countries; $R E X_{t}$ is the real effective exchange rate between Nigeria and its trading partner countries which is adjusted by consumer price index to reflect the actual changes between countries and $\varepsilon_{t}$ is the stochastic error term. It is expected that estimates of domestic real income and foreign real income to be positive. While the relationship

\footnotetext{
${ }^{1}$ These studies discovered that there is asymmetric relationship between exchange rate movement and trade balance ( see, for example, Duasa,2009; Verheyen, 2013, Bussiere, 2013; Shimizu and sato, 2015; BahmaniOskoee et al, 2016; Bahmani-Oskoee and Fariditavana, 2016; Akosah and Adjepong, 2017; Arize et al, 2017; Bahmani-Oskoee and Aftab, 2017; Buba et al, 2018 and Chi, 2018 among others).

${ }^{2}$ Using monthly data for the period of June 1999-April 2012, Aliyu and Tijjani (2015) employed Threshold Autoregressive Model (TAR) to examine the asymmetric cointegration relationship between exchange rate and trade balance in Nigeria. The estimated asymmetric error correction models provide new evidence for slower transmission of exchange rate depreciations into the country's trade balance, which in turn appears to offer partial support for the Dutch disease hypothesis.
} 
between real exchange rate and trade balance is ambiguous, suggesting that the estimate of real exchange rate can be positive or negative. Overtime, there has been no consensus among the researchers with respect to the econometric techniques which best suited to capture the exchange rate- trade nexus and most of the econometric techniques employed often lead spurious results.

Appraising the validity of J-curve and Marshal-Lerner hypothesis ${ }^{3}$ is one of the core objectives of this study. To achieve this, a linear ARDL model introduced by Pesaran et al $(2001)^{4}$ is first employed to capture both time horizons (short run and long run relationships) and equally show the symmetric relationships between exchange rate changes and trade balance in the case of Nigeria. The unrestricted error correction model (UECM) version of the ARDL model is presented as follows:

$$
\begin{aligned}
\Delta \ln T B_{t}= & \beta_{0}+\sum_{k=1}^{p_{1}} \beta_{k 1} \Delta \ln T B_{t-k}+\sum_{k=0}^{p_{2}} \beta_{k 2} \Delta \ln Y_{t-k}^{D}+ \\
& \sum_{k=0}^{p_{3}} \beta_{k 3} \Delta \ln Y_{t-k}^{F}+\sum_{k=0}^{p_{4}} \beta_{k 4} \Delta \ln R E X_{t-k}+ \\
& \delta_{1} \ln T B_{t-1}+\delta_{2} \ln Y_{t-1}^{D}+\delta 3 \ln Y_{t-1}^{F}+\delta_{4} \ln R E X_{t-1}+\varepsilon_{t}
\end{aligned}
$$

Where $\Delta$ is the first difference operator; $\beta_{k i}$ are the coefficient estimates of the chosen variables; $p_{i}$ represents the optimal lag lengths selected based on the optimal length selection criterions. Pesaran et al (2001) then propose an F-test for joint significance of the coefficients of the lagged level of variables to confirm the existence of cointegration among the variables. For example, the null hypothesis of no long run relationship between the variables is $H_{0}: \delta_{1}=\delta_{2}=$ $\delta_{3}=\delta_{4}=0$ is tested against the alternative hypothesis of cointegration $H_{0}: \delta_{1} \neq \delta_{2} \neq \delta_{3} \neq$ $\delta_{4} \neq 0$. Furthermore, Pesaran et al (2001) then computed two set of critical values (lower and upper critical bounds) for a given significance level in which the lower critical bound is denoted as $I(0)$ and the upper critical bound is denoted as $I(1)$. If the F-statistic exceeds the upper critical value, then the null hypothesis will be rejected in favour of the alternative hypothesis and thus concluded that there is long run relationship. If the F-statistics falls below both critical bounds, the null hypothesis of no cointegration is accepted. However, if the F-statistics lies between the lower and upper critical bounds, inference will be inconclusive.

Having argued among the researchers that firms or producers respond differently to exchange rate changes, that is, depreciation or appreciation of a currency may have a different impact on trade balance at the same magnitude. Thus, this lead this study to further examine the asymmetric relationships between exchange rate changes and trade balance using recently developed NARDL proposed by Shin et al $(2014)^{5}$. Where the real exchange rate is decomposed into two partial sum process of positive and negative as follow:

\footnotetext{
${ }^{3} \mathrm{~J}$-curve postulates that the depreciation or devaluation of domestic currency initially cause a trade deficit (volume of import exceed volume of export) for a country but improve the trade balance in the long run. While Marshal-Lerner hypothesis states that depreciation or devaluation of domestic currency will only improve a country's trade balance if the sum of import and export elasticities exceeds unity.

${ }^{4}$ This model is found to be applicable irrespective of the order of integration of variables, evades the need for pre-testing the integration order of variables, allows the variables to have different optimal lag length, possibility of deriving a dynamic unrestricted error correction model from the approach via a simple linear transformation and it integrates both the short run dynamics and long run dynamics together without loss of any long run information (see Narayan and Smith, 2005; Dzanan and Masih, 2017; Chi, 2018; and Bahmani-Oskoee and Karamelikli, 2018 ).

${ }^{5}$ NARDL approach allows a relationship to exhibit both short-run and long-run asymmetries. It also offers the possibility of quantifying the respective responses of the regressand to positive and negative shocks of the regressors from the asymmetric dynamic multipliers (see Arize et al , 2017).
} 


$$
\begin{aligned}
& \ln R E X_{t}^{+}=\sum_{j=1}^{t} \Delta \ln R E X_{j}^{+}=\sum_{j=1}^{t} \max \left(\Delta \ln R E X_{j}^{+}, 0\right) \\
& \ln R E X_{t}^{-}=\sum_{j=1}^{t} \Delta \ln R E X_{j}^{-}=\sum_{j=1}^{t} \min \left(\Delta \ln R E X_{j}^{-}, 0\right)
\end{aligned}
$$

Then, the two partial sum processes ( $\ln R E X_{t}^{+}$and $\ln R E X_{t}^{-}$) is substituted into Eq. (2.2) to replace $\ln R E X_{t}$. Thus, the error-correction model of NARDL is expressed as follow:

$$
\begin{aligned}
\Delta \ln T B_{t}= & \beta_{0}^{\prime}+\sum_{k=1}^{p_{1}} \beta_{k 1}^{\prime} \Delta \ln T B_{t-k}+\sum_{k=0}^{p_{2}} \beta_{k 2}^{\prime} \Delta \ln Y_{t-k}^{D}+\sum_{k=0}^{p_{3}} \beta_{k 3}^{\prime} \Delta \ln Y_{t-k}^{F} \\
& +\sum_{k=0}^{p_{4}} \beta^{\prime} \ln R E X_{t-k}^{+}+\sum_{k=0}^{p_{5}} \beta_{k 5}^{\prime} \Delta \ln R E X_{t-k}^{-}+ \\
& \delta_{1} \ln T B_{t-1}+\delta_{2} \ln Y_{t-1}^{D}+\delta_{3} \ln Y_{t-1}^{F}+\delta_{4} \ln R E X_{t-1}^{+}+\delta_{5} \ln R E X_{t-1}^{-}+\varepsilon_{t}
\end{aligned}
$$

To estimate the long run relationship or Cointegration among the variables, Shin et al (2014) recommends that the bound test introduced by Pesaran et al (2001) can equally be employed to detect the Cointegration relationship among the variables due to the dependency between the two partial sum variables. Bahmani-Oskoee and Aftab (2017) note that once the error-correction model and Cointegration are established, there are certain rules of thumb of asymmetric approach to be considered which are stated as follow:

Firstly, determination of the existence of short run asymmetric by comparing if the size and sign of the two short run partial sum variables estimates are different i.e. $\beta \prime_{k 4} \neq \beta_{k 5}^{\prime}$. Secondly, determination of the existence of long run asymmetric by comparing if the size and sign of the two long run partial sum variables estimated are different i.e. $\delta_{4} \neq \delta_{5}$. Lastly, verifying the possibility of the two short run partial sum variables having different lag orders using the Wald test to conduct these tests.

\section{Data and Empirical Results}

3.1. Data. This study investigates the asymmetric effect of exchange rate changes on trade balance in Nigeria using quarterly data spanning from 1999Q1 to 2017Q4. The choice of the time period and variables employed are mainly dictated by the periods that mark the liberalization of foreign exchange markets ${ }^{6}$, transition from military regime to democratic government regime, theoretical underpinning of previous studies and data availability. All variables used are sourced from World Development Indicators Database (CD- ROM 2017) and Central Bank of Nigeria, Statistical Bulletin (2017) and they are equally transform into logarithmic form to avoid spurious results and detect the problems of autocorrelation and heteroskedacticity.

3.2. Empirical Results. The descriptive statistics and the pair-wise correlation among the variables are reported in Table 1 . Table 1 show that all series have positive average with the highest and lowest mean reported in foreign real income and trade balance respectively. The positive average reported suggests that the Nigerian currency is depreciating against the trading partners 'currencies. The standard deviation that measures variability reveals that all the series do not exhibit large variation around the means since the values of all series are less than one. The minimum and maximum values are not large and are also in consonance with the standard

\footnotetext{
${ }^{6}$ Prior to the liberalization or introduction of different foreign exchange markets in Nigeria, there was dearth of accessibility of foreign exchange by end-users to facilitate their transaction which results in exchange rate volatility and almost crumble the economy. To combat this menace, different policies were introduced that led to the introduction of different foreign exchange markets such as Autonomous foreign exchange market (AFEM), Inter-bank foreign exchange market (IFEM) and Dutch Auction System (DAS) respectively.
} 
deviation. The skewness statistics that measures lack of symmetry in the observation show that all series exhibit negative skewness except trade balance series, suggesting the presence of asymmetry and the kurtosis statistics shows that all the series are platykurtic and do not have fat tails. Furthermore, the Jarque-Bera statistics confirms that all series are normally distributed since the values of the series are statistically insignificant.

The extent of association among the variables is also reported in lower part of Table 1.The correlation analysis shows that real exchange rates is positively correlated with the trade balance. The correlation between trade balance and domestic real income is also found to be positive. Furthermore, the analysis reports the existence of a positive correlation between domestic real GDP and foreign GDP. Trade balance is positively but insignificantly correlated with foreign GDP. Exchange rates change is positively correlated with trade balance, domestic real GDP and foreign GDP. Now, to estimate the asymmetric effect of exchange rate changes on trade balance in Nigeria, it is imperative to first ascertain the order of integration of the variables by conducting the unit root tests to determine the stationarity of all variables in order to avoid spurious results ${ }^{7}$.

\begin{tabular}{|l|r|r|r|r|}
\hline \multicolumn{5}{|c|}{ Table 1. Descriptive and Correlation statistics } \\
\hline Variables & \multicolumn{1}{l}{$\ln \mathbf{Y}_{t}^{D}$} & \multicolumn{1}{l}{$\ln \mathbf{Y}_{t}^{F}$} & $\ln \mathbf{R E X}_{t}$ & $\ln \mathbf{T B}_{t}$ \\
\hline Mean & 26.3168 & 31.7231 & 4.54138 & 0.3302 \\
\hline Median & 26.3978 & 31.7564 & 4.5597 & 0.3509 \\
\hline Maximum & 26.8631 & 31.9821 & 4.8473 & 0.9679 \\
\hline Minimum & 25.6991 & 31.443 & 4.2255 & -0.2059 \\
\hline Standard Deviation & 0.4295 & 0.1694 & 0.1986 & 0.299 \\
\hline Skewness & -0.2269 & -0.136 & -0.0889 & 0.4178 \\
\hline Kurtosis & 1.51419 & 1.7757 & 1.8179 & 2.81 \\
\hline Jarque-Bera & 2.0114 & 1.3107 & 1.1906 & 0.6121 \\
\hline Prob & 0.3657 & 0.5192 & 0.5513 & 0.7362 \\
\hline Sum & 526.377 & 634.4636 & 90.8276 & 6.6045 \\
\hline Sumq & 3.50564 & 0.5458 & 0.74974 & 1.69899 \\
\hline $\ln Y_{t}^{D}$ & 1 & & & \\
\hline $\ln Y_{t}^{F}$ & 0.987 & & & \\
\hline $\ln R E X_{t}$ & 0.94372 & 0.9233 & & \\
\hline $\ln T B_{t}$ & 0.1039 & 0.0068 & 0.220 & 1 \\
\hline
\end{tabular}

Note: $\ln Y_{t}^{D}$ is the domestic real income, $\ln Y_{t}^{F}$ is the real income of trading countries, $\ln R E X_{t}$ is the Real exchange rate and $\ln T B_{t}$ is trade balance.

Having established that there exists stationarity among the variables. Hence, this study proceeds to confirm the existence of long run cointegration relationship between the variables using the Pesaran et al (2001) bound tests. In doing this, the study is first subject to determining the optimal lag length of the model using different selection criteria ${ }^{8}$ due to sensitivity of F-statistics to lag length. The empirical results of the linear and non-linear ARDL bound tests are illustrated in Table 2. The results show that the F-statistics of the linear and nonlinear cointegration relationship exceed the upper bound of the critical value $\left(F_{p s s}=6.13\right.$; $\left.F_{p s s}=7.26\right)$, implying that the null hypothesis of no long run cointegration is rejected at $1 \%$ significant levels. These findings therefore confirm that there is the existence of long run cointegration relationships between real exchange rate and trade balance in both linear and non-linear ARDL models.

\footnotetext{
${ }^{7}$ Using ADF, PP and KPSS unit root and stationarity tests, the results of the tests show that all variables are stationary at first difference with both constant and trend, except some variables that were found to be stationary at level. However, the results are not presented in this paper, but it is available upon request.

${ }^{8}$ The lag selection criterion results produced a mixed results, this lead to choosing Schwartz Information Criterion (SIC) as the optimal lag length due to its consistency and parsimonious in lag length selection and also, to avoid losing a lot of degree of freedom.
} 


\begin{tabular}{|}
\hline Table 2. Bound Test for cointegration in the linear and Non-linear specification \\
\hline Model & F-stat & ECM (-1) & Value 1\% & Value 5\% & Value 10\% \\
\hline \multicolumn{5}{|c|}{ Linear ARDL } \\
\hline $1,0,1,0,1$ & $6.135^{* * *}$ & -0.87 & $\mathrm{I}(0)=3.65$ & $\mathrm{I}(0)=2.79$ & $\mathrm{I}(0)=2.37$ \\
\hline & & $\mathrm{I}(1)=4.66$ & $\mathrm{I}(1)=3.67$ & $\mathrm{I}(1)=3.20$ \\
\hline \multicolumn{5}{|c|}{ Non-Linear ARDL } \\
\hline $1,2,0,2,2$ & $7.2606^{* * *}$ & -0.56 & $\mathrm{I}(0)=3.29$ & $\mathrm{I}(0)=2.56$ & $\mathrm{I}(0)=2.2$ \\
\hline & & $\mathrm{I}(1)=4.37$ & $\mathrm{I}(1)=3.49$ & $\mathrm{I}(1)=3.09$ \\
\hline
\end{tabular}

Note: $* * *, * *$ and $*$ indicate significance levels for $1 \%, 5 \%$ and $10 \%$ respectively.

Following the confirmation of long run relationship between the variables, this study now examine the asymmetric effect of exchange rate changes on trade balance in Nigeria. For comparison purpose, the results of both linear and Non-linear ARDL are depicted in Table 3 and Table 4 respectively. The linear ARDL results show that the coefficient of domestic real income with respect to trade balance is negative and statistically significant ${ }^{9}$, suggesting that a $1 \%$ increase in economic growth of Nigeria will reduce the trade balance by $0.574 \%$. However, positive insignificant relationship is found between foreign real income and trade balance in the long run. This finding suggests that increase in economic growth of trading partner countries does not transform into improvement in trade balance of Nigeria due to shortfall in demand for Nigeria's export goods that will correct the trade deficit. In other words, this finding implies that economic growth of the trading partner countries does not contribute significantly to the improvement in Nigeria's trade balance. The estimated coefficient of real exchange rate apparently does not exert significant impact on the trade balance in the long run which implies that real depreciation of Naira against basket of currencies does not lead to improvement in the trade balance in the long run. The plausible rationale for the insignificance relationship between the real exchange rate and trade balance could be attributed to the possible asymmetric relationship between the variables.

The results of the parsimonious error correction model with lagged and current periods are also presented in Table 3. The estimated coefficient of domestic real income is positively significant in influencing trade balance in the short run ${ }^{10}$. Specifically, the findings show that a $1 \%$ increase in economic growth of Nigeria will improve the trade balance by $0.344 \%$ in the short run .Similarly, foreign real income adds significantly to improvement in trade balance in the short run as expected, suggesting that a $1 \%$ increase in foreign real income leads to improvement in Nigeria's trade balance by $0.3 \%$ in the short run. However, the coefficient of real exchange is positive but not statistically different from zero in the short run, implying that depreciation of Naira against the basket of currencies does not have short run improvement on the trade balance of Nigeria.

It is essential that the selected model is also subjected to robust check to increase the predictive power of the study. To achieve this, different diagnostic tests are conducted and the results are illustrated in lower part of Table 3. The results show that the estimated model passes the Langrangier multiplier test of serial correlation, Ramsey's RESET test of misspecification and normality test since their statistics are statistically insignificant. Furthermore, the stability of long run and short run estimates are assessed by the CUSUM and CUSUMQ tests ${ }^{11}$. The error correction term $\left(E C M_{t-1}\right)$ is negative and statistically significant, suggesting adjustment towards the long run equilibrium and this is also supported by the F-statistics results.

\footnotetext{
${ }^{9}$ The finding of negative relationship between domestic real income and trade balance is not surprising as increase in economic growth of Nigeria often lead to more increase in the importation of foreign goods which consequently deteriorate the trade balance due to large differential between the import and export of the country.

${ }^{10}$ This finding is consistent with the findings of Adeniyi (2011), Eke et al (2015), Igue and Ogunleye (2014) and Dzanan and Masih (2017).

${ }^{11}$ It should note that the graphical representation of the CUSM and CUSUMQ are not presented in this study. But, they are available upon request by the author.
} 


\begin{tabular}{|c|c|c|c|}
\hline \multicolumn{4}{|c|}{ Table 3. Results of linear ARDL model } \\
\hline Dependent Variable: $\ln T B$ & & \\
\hline Variable & Coefficient & T-stat & P-value \\
\hline Constant & 0.2688 & 0.005 & 0.487 \\
\hline $\ln Y_{t-1}^{D}$ & $-1.6642^{* *}$ & 1.419 & 0.057 \\
\hline $\ln Y_{t-1}^{F}$ & 0.9558 & 0.379 & 0.1960 \\
\hline $\ln R E X_{t-1}$ & -2.9926 & 2.583 & 0.124 \\
\hline$\Delta \ln T B_{t-1}$ & $-0.9547^{* * *}$ & 4.605 & 0.000 \\
\hline$\Delta \ln Y_{t-1}^{D}$ & $1.3436^{* *}$ & 1.229 & 0.047 \\
\hline$\Delta \ln Y_{t-1}^{F}$ & $0.7975^{* * *}$ & 1.631 & 0.003 \\
\hline$\Delta \ln Y_{t-2}^{F}$ & $0.5437^{* *}$ & 0.2783 & 0.0349 \\
\hline$\Delta \ln R E X_{t-1}$ & 2.6649 & 2.8321 & 0.3141 \\
\hline$F_{p s s}=6.13^{* * *}$ & & $C=$ Stable & $C_{q}=$ Stable \\
\hline \multicolumn{2}{|c|}{$X_{S C}^{2}=1.803(0.594)$} & $X_{H}^{2}=2.5785(0.2410)$ \\
\hline \multicolumn{2}{|c|}{$X_{F F}^{2}=0.1064(0.7424)$} & $X_{N}^{2}=0.1372(0.1254)$ \\
\hline
\end{tabular}

Note: $* * * * *$ and $*$ indicate significance levels for $1 \%, 5 \%$ and $10 \%$ respectively.

$F_{p s s}$ Denotes F-statistics testing the cointegration, $C$ and $C_{q}$ signifies CUSUM and CUSUMQ respectively.

$X_{S C}^{2}, X_{H}^{2}, X_{F F}^{2}$ and $X_{N}^{2}$ represent LM test for serial correlation, heteroskedacticity, RAMSEY'S RESET test and normality respectively.

Now the results of the asymmetric effect of exchange rate changes on trade balance are presented in Table 4. The results show that domestic real income is negative and statistically significant in both time horizons indicating that as the economic growth of Nigeria increases; trade balance will deteriorate. Specifically, the results show that a $1 \%$ increase in economic growth of the country will reduce the trade balance by $0.519 \%$ in the long run and $0.978 \%$ in the short run respectively. In contrast, the estimated coefficient of foreign real income is positively significant in influencing trade balance in both short run and long run. This finding suggests that increase in economic growth of trading partner countries will enhance the demand for Nigeria's export goods which consequently improve the trade balance in Nigeria by $0.078 \%$ in the long run and $0.342 \%$ in the short run respectively. In addition, the estimated coefficients of positive (appreciation) and negative (depreciation) sum decomposition of real exchange changes are negative. For example, the long run coefficient of real exchange appreciation (depreciation) with respect to trade balance are $-0.313(-0.594)$ indicating that a $1 \%$ depreciation (appreciation) of Naira against the basket of currencies will magnify (dampen) trade balance by $0.313 \%(0.594 \%)$. Statistically, it is highly significant for positive real exchange and insignificant for negative real exchange. Similarly, the short run results also report that the two estimates are negative, suggesting that a 1\% depreciation (appreciation) of Naira against the basket of currencies will improve (deteriorate) trade balance by $0.389 \%(0.737 \%)$. Statistically, it is also significant only in the case of positive real exchange but insignificant in negative real exchange.

To further ascertain the asymmetric relationship between the real exchange rate and trade balance, the existence of possible equality between positive and negative coefficients for each variable in both time horizons is also reported using the Wald Test. The null hypothesis of no long run asymmetry is rejected at 5\% significant level, confirming the existence of long run asymmetric effect of real exchange rate changes on trade balance. While the null hypothesis of no short run asymmetry cannot be rejected even at $10 \%$ significant level. The lower part of Table 4 also illustrates the diagnostics test results of the estimated model. The results show that the model possess the required econometric properties since there is absence of serial correlation, misspecification and heteroskedacticity as reported in the linear ARDL results

Overall, inferring based on the findings of linear relationships without considering the nonlinear or asymmetric relationship between these variables will generate spurious findings and also lead to wrong policy implications for the country. The findings confirm that real exchange 
rate is asymmetrically related to trade balance. Specifically, trade balance is sensitive to changes in the exchange rate.

\begin{tabular}{|c|c|c|c|}
\hline \multicolumn{4}{|c|}{ Table 4. Results of Non-linear ARDL model } \\
\hline Dependent variable: $\ln T B$ & & \\
\hline Variable & Coefficient & T-stat & P-value \\
\hline Constant & $2.335^{* *}$ & 2.2321 & 0.037 \\
\hline $\ln Y_{t-1}^{D}$ & $-0.5192^{* * *}$ & 1.9466 & 0.0073 \\
\hline $\ln Y_{t-1}^{F}$ & $0.0783^{* *}$ & 2.5094 & 0.0261 \\
\hline $\ln R E X_{t-1}^{+}$ & $-0.3138^{* * *}$ & -0.2344 & 0.0018 \\
\hline $\ln R E X_{t-1}^{-}$ & -0.594 & -3.9361 & 0.6894 \\
\hline$\Delta \ln T B_{t-1}$ & $-1.2412^{* * *}$ & -5.7406 & 0.0001 \\
\hline$\Delta \ln Y_{t-1}^{D}$ & $-0.9781^{*}$ & -1.9640 & 0.0741 \\
\hline$\Delta \ln Y_{t-1}^{F}$ & $0.3427^{* *}$ & 2.2169 & 0.0451 \\
\hline$\Delta \ln R E X_{t-1}^{+}$ & $-0.3895^{* * *}$ & -0.2307 & 0.0063 \\
\hline$\Delta \ln R E X_{t-1}^{-}$ & -0.7370 & -3.5241 & 0.8211 \\
\hline$L_{R E X}^{+}=0.4638(0.030)$ & $L_{R E X}^{-}=0.6209(0.081)$ \\
\hline$X_{S C}^{2}=2.329(0.142)$ & $X_{H}^{2}=0.7484(0.399)$ \\
\hline$X_{F F}^{2}=2.4701(0.142)$ & $X_{N}^{2}=0.740(0.690)$ \\
\hline$W_{L R, r e x}=3.857(0.037)$ & $W_{S R, r e x}=2.419(0.171)$ \\
\hline \multicolumn{2}{|c|}{} \\
\hline \multicolumn{2}{|c|}{$F_{p s s}=7.260^{* *}$} & \multicolumn{2}{|c}{} \\
\hline
\end{tabular}

Note: $* * *, * *$ and $*$ indicate significance levels for $1 \%, 5 \%$ and $10 \%$ respectively . $F_{p s s}$ denotes F-statistics testing the cointegration. $X_{S C}^{2}, X_{H}^{2}, X_{F F}^{2}$ and $X_{N}^{2}$ depict LM test for serial correlation, heteroskedacticity, RAMSEY'S RESET test and normality respectively. $L_{R E X}$ is the estimated long run coefficient. $W_{L R, \text { rex }}$ and $W_{S R \text {,rex }}$ are the Wald tests for long run asymmetry and short run asymmetry respectively.

\section{Concluding Remarks}

Previous studies concluded that the relationship between real exchange rate changes and trade balance is symmetric. Thus, this study attempt to question this assumption by estimating the asymmetric relationship between exchange rate changes and trade balance in the case of Nigeria over the period 1999Q1-2017Q4 using Non-linear ARDL model proposed by Shin et al (2014). The empirical findings show that increase in foreign real income of trading partner countries play important roles in the trade balance in Nigeria. On the contrary, the increase in domestic real income tends to deteriorate trade balance in both time horizons. Furthermore, the relationship between real exchange rate and trade balance is found to be asymmetric. Specifically, trade balance is sensitive to changes in the exchange rate. Based on the findings above, the significant result of real exchange rate is not surprising as most monetary policies implemented in Nigeria are discretionary in nature. From 1960 till date, two monetary policies have mainly been employed such as exchange rate targeting (1959-1973) and monetary targeting (1973 till date). Furthermore, since the introduction of Structural Adjustment Program (SAP) in 1986, different policies have been implemented to mitigate against exchange rate volatility and depreciation of domestic currency which consequently affect the trade balance. It is generally established that employing contractionary monetary policy induces increase in interest rate and leads to appreciation of domestic currency relative to other currencies, thereby cause increase in the importation of foreign goods relative to goods export to other countries with the resultant effect on trade balance. These findings therefore suggest that using discretionary monetary policy to offset Nigeria's trade deficit due to large differential between import and export is not sufficient enough. Thus, policy makers should adopt policy-mix to manage the current economic climate of the country such as imposition of quotas on certain imported goods, high tariff rate on imported goods, provision of credit facilities and higher tax rate that reduce disposable income of consumer. 


\section{REFERENCES}

[1] Adeniyi, O., Omisakin, O. \& Oyinlola, A. (2011). Exchange rate and trade balances in West Africa Monetary zone: Is there a J-curve. International Journal of Applied Economics and Finance, 5 (3), 167-176.

[2] Aliyu, A \& Shehu Mohammed Tijjani (2015). Asymmetric cointegration between exchange rate and trade balance in Nigeria, Cogent Economics \&Finance (2015), 3: 1045213.

[3] Akosah, N.K \& Adjepong, M.O (2017). Exchange Rate and External Trade Flows: Empirical Evidence of J-Curve Effect in Ghana, MPRA Paper No. 86640, posted 11 May 2018 13:25 UTC https://mpra.ub.unimuenchen.de/86640/.

[4] Atsegbua, L. A. (2012). The Nigerian oil and gas industry content development act 2010: An examination of its regulatory framework. OPEC Energy Review, 36, 479-494.http://dx.doi.org/10.1111/opec.2012.36.issue4.

[5] Augustine C. Arize, John Malindretos and Emmanuel U. Igwe (2017). Do Exchange Rate Changes Improve the Trade Balance: An Asymmetric Nonlinear Cointegration Approach, International Review of Economics and Finance, http://dx.doi.org/10.1016/j.iref.2017.02.007.

[6] Bahmani-Oskoee, M. and H. Fariditavana (2015), "Nonlinear ARDL Approach, Asymmetric Effects and the J-Curve", Journal of Economic Studies, Vol. 42, pp. 519-530

[7] Bahmani-Oskoee, Mohsen, Halicioglu, Ferda, Asymmetric effects of exchange rate changes on Turkish bilateral trade balances. Economic System http://dx.doi.org/10.1016/j.ecosys.2016.07.001.

[8] Bahmani-Oskoee, Mohsen, \& Baek, Jungho. Do Exchange Rate Changes have Symmetric or Asymmetric Effects on the Trade Balance? Evidence from U.S.-Korea Commodity Trade. Journal of Asian Economics http://dx.doi.org/10.1016/j.asieco.2016.06.001.

[9] Bahmani-Oskoee M, Karamelikli H, Japan-U.S. Trade Balance at Commodity Level and Asymmetric Effects of Yen-Dollar Rate, Japan and The World Economy (2018), https://doi.org/10.1016/j.japwor.2018.06.002.

[10] Bahmani-Oskoee M, \& Aftab, M (2018). Asymmetric effects of exchange rate changes on the MalaysiaChina commodity trade. (In Press).

[11] Bhattarai, K. R. and M. K. Armah (2005), 'The Effects of Exchange Rate on the Trade Balance in Ghana: Evidence from Cointegration Analysis', Research Memorandum, No. 52.

[12] Buba, S., Ibrahim Al-jadi, S.M and Guza, G.M (2018). Asymmetric Co-integration between Exchange Rate and Trade Balance in Thailand, World Journal of Economic and Finance Vol. 4(1), pp. 075-084.

[13] Bussiere, M. (2013), "Exchange rate Pass-through to Trade Prices: The Role of Nonlinearities and Asymmetries", Oxford Bulletin of Economics and Statistics, Vol. 75, pp. 731-758.

[14] Chi, J. (2018). Asymmetric effects of exchange rate and income changes on maritime freight flows between Japan and the US, Transport Policy 69 (2018) 158-169.

[15] Duasa, J. (2009). Asymmetric cointegration relationship between real exchange rate and trade variables: The case of Malaysia (MPRA Paper No. 14535). Retrieved from http://mora.ub.uni-muenchen.de/14535/.

[16] Demian, C.-V., di Mauro, F., The exchange rate, asymmetric shocks and Asymmetric distributions, International Economics (2017), doi: 10.1016/j.inteco.2017.10.005.

[17] Dzanan, H and Masih, M (2017). Does currency depreciation necessarily result in positive trade balance? New evidence from Norway, https://mpra.ub.uni-muenchen.de/82103/.

[18] Eke, I.C \& Eke., F.A., \& Obafemi, F.N (2015). Exchange Rate Behaviour and Trade Balances in Nigeria: An Empirical Investigation. International Journal of Humanities and Social Science, Vol. 5, No. 8(1).

[19] Igue, N. N., \& Ogunleye, T. S. (2014). Impact of real exchange rate on trade balance in Nigeria. African Development Review, 26, 347-358. http://dx.doi.org/10.1111/afdr.v26.2

[20] Kodongo, O., Ojah, K. (2011). Real exchange rate, trade balance and capital flow in Africa. Journal of Economics and Business, 66 (2013) 22- 46.

[21] Michael, E.O, \& Emeka, A (2017). An Empirical Analysis of the Impact of Exchange Rate Devaluation on Trade Balance of Nigeria: Vector Error Correction Model Approach, Asian Journal of Economics, Business and Accounting, 3(3): 1-15, 2017; Article no.AJEBA.33355 ISSN: 2456-639X.

[22] Narayan, P.K., Smyth, R., (2005). Trade liberalization and Economic growth in Fiji: An empirical assessment using the ARDL approach. Journal of the Asia Pacific Economy 10, 96-115.

[23] Ogundipe, A. A., Ojeaga, P., \& Ogundipe, O. M. (2013). Estimating the long run effects of exchange rate devaluation on the trade balance of Nigeria. European Scientific Journal, 9, 233-249.

[24] Pesaran, M. H., Shin, Y., \& Smith, R. J. (2001). Bounds testing approaches to the analysis of level relationships. Journal of Applied Econometrics, 16, 289-326.

[25] Rose, A. K., and J. L. Yellen (1989), "Is There a J-curve?" Journal of Monetary Economics 24, 53-68.

[26] Sato, K., J. Shimizu, N. Shrestha and S. Zhang (2013) "Industry-specific Real Effective Exchange Rates and Export Price Competitiveness: The Cases of Japan, China and Korea," Asian Economic Policy Review, Vol. 8, pp.298-321.

[27] Shin, Y., Yu, B.C. and M. Greenwood-Nimmo (2014), "Modelling Asymmetric Cointegration and Dynamic Multipliers in a Nonlinear ARDL Framework" in Sickels, R. and Horrace, W. (Eds), "Festschrift in Honor of Peter Schmidt: Econometric Methods and Applications," Springer, New York, NY, 281-314. 
[28] Tunaer Vural, B.M (2015). Effect of Real Exchange Rate on Trade Balance: Commodity Level Evidence from Turkish Bilateral Trade Data. Procedia Economics and Finance 38 (2016) $499-507$.

[29] Umoru, D., \& Oseme, A.S (2013). Trade Flows and Exchange Rate Shocks in Nigeria: An Empirical Result. Asian Economic and Financial Review, 2013, 3(7):948-977.

[30] Wang, C.H, Lin, C.A \& Yang, C (2012). Short-run and long-run effects of exchange rate change on trade balance: Evidence from China and its trading partners, Japan and the World Economy 24 (2012) 266-273 